\title{
Sense of Safety and Planning and Design Policies
}

\author{
Rangajeewa Ratnayake ${ }^{1}$, Naduni Wickramaarachchi ${ }^{2}$, Julie Rudner ${ }^{3}$ \\ 1 Universty of Moratuwa \\ 2 \& 3 Latrobe University, Australia
}

Corresponding Author- Rangajeewa Ratnayake, email rangajeewar@uom.lk

\begin{abstract}
Planning, development and design policies influence sense of safety of people to use the City centre or Central Business District (CBD) and therefore city centres can become active and vibrant during the day and night. This paper reviews past and present planning policies relevant for feeling of personal safety in the context of housing, retail, amenities, street infrastructure, building design and transportation aspects. The past development trends show that insignificant attention has been paid to people's sense of safety when using public spaces, particularly at night, a factor identified important in creating attractive city centres since 1960s. Local plans primarily refer to safety in relation to roads, accessibility and workability. Local policies also show the dominance of CCTV since the 1990s has become ubiquitous, but changes to sense of safety in urban spaces now may actually be a better reflection of planning and design decisions made over the past 20 years.
\end{abstract}

Keywords: CBD; planning and design policies; sense of safety

\section{Introduction}

Fear of crime or sense of feeling of insecurity at night is a type of fear experienced by individuals in their day-to-day life when they use public spaces and take public transport. The perception of safety influences people's decision on whether to use or avoid urban public spaces, and it limits activities particularly at night in city centres. If people avoid public spaces particularly at night due to fear of crime (De Silva, Waruwawitharana \& Ratnayake, 2017), such spaces become less vibrant, visually unattractive and less stimulating for residents and visitors (Ratnayake, 2017). The past studies show that the incidence of crime within the Bendigo CBD was not particularly high, however, the perception within the community was that the CBD area was unsafe particularly at night (City of Greater Bendigo, 2004a). City Councils have attempted to address this issue through multiple strategies. For example, improving physical lighting, installation of Closed CircuitTelevision Cameras (CCTV), land use changes and building designs. Considering Bendigo CBD area, the aim of this paper is to review to what extent the planning and design policies and strategies have addressed sense of safety concerns in particularly last three decades. Therefore, this paper presents information about the recent development initiatives of the Bendigo CBD area relevant to safety. Policies such as housing in CBD area, retail developments, transport proposals and various services are discussed in this connection.

\section{Environmental design approaches and sense of safety}

Crime prevention and enhancing sense of safety concerns have been discussed in planning and urban design literature since 1960s (Jacob, 1961; Newman, 1972). Crime Prevention 
Through Environmental Design (CPTED) is considered as a key approach that has been introduced to prevent situational crime and reduce fear by modifying the some aspects of the built environment. CPTED is explained as the 'proper design and effective use of the built environment can lead to a reduction in the fear of crime and incidents of crime'(Crowe, 2000: 46). The improvement of quality of street lighting, natural surveillance, territoriality, access control and an effective demarcation between private and public spaces play (Defensible Space) are accepted as some important CPTED measures to reduce fear and crime in streets (Jacobs, 1961; Ratnayake, 2013; Ratnayake, 2016; Winkel and Vrij, 1991). Findings of qualitative walk talks or observation studies have proved that environmental improvements ( lighting, mix uses, visibility etc.) can influence people's sense of safety (Ratnayake, 2014).

Situation Prevention of Crime (SPC) is another environmental deterministic approach to deter crime and enhancing sense of safety. Based on CPTED ideas, the SCP approach was initially developed within the United Kingdom (UK) and then widely used in America (Crowe, 2000). Situational measures are aimed at either reducing the physical opportunities for offending or increasing the chances of an offender being caught. This approach proposes measures such as instalment of locks, vandal resistant designs, neighbourhood watch initiatives, intruder alarms, CCTV cameras and defensible space recommendations proposed by Newman (1972). A major criticism to SPC and defensible space ideas was that such spaces tended to produce gated communities and such spaces exclude strangers and subsequently those areas will lose the informal social control (Hilier and Hanson, 1984: 141; Jacob, 1961: 41).

In 1961, Jane Jacob, wrote an influential book, 'The Death and Life of Great American Cities. Much of Jacob's ideas in this book were critics for modernists' planning (Frank Lloyd Wright's and Le Corbusier's designs) as such planning practices have contributed to destroy old city centres and consequently increase crime and unsafely. Wright thought that decentralization (suburbia) would insure community life with modern telecommunications and transportation developments (Gates and Stout, 2003). Le Corbusier argued that old city centre is dying and developed haphazardly because it is not geometrical; therefore he believed that city should be constructed vertically to accommodate high density of people (Gates and Stout, 2003). Jacob argued that the modernism of Le Corbusier and Wright tended to create publicly unregulated spaces and avoidance of using city centre. She considered these modernists' developmental forms have contributed rising crime rate. On the contrary, Jacob argued that urban spaces, such as streets and city squares should be designed with the approach on 'eyes on the street' and mixed land uses.

CCTV cameras have been used widely in city centres to enhance security in public spaces in recent years. Security cameras can have an effect on reduction of crime. However, Trench, and Tiesdell (1991) showed that CCTV does not make women feel safer. Similarly, a more recent study finding in UK also shows that CCTVs do not significantly improve safe feeling when walking at night (Lorenc et al., 2013). It appears that the idea of enhancing feelings of safety from remote surveillance devices contradicts Jacob's ideas as she argues for the mixed use of zoning and the heavy use of sidewalks to increase 'natural surveillance'.

From the literature above, it seems that numerous planning and design measures have been developed and implemented in local urban areas to reduce crime and make people feel safe at night. However, we know little about planning policy and design measures that have been used to address particularly fear of crime or personal safety concerns in an Australian regional cities. Therefore, this study aims to assess recent development initiatives of the Bendigo CBD area relevant to safety. The current study mainly used published local level reports and plans to pursue the research aim. 
Bendigo planning history in brief

The Bendigo CBD plan was developed by a surveyor known as Richard Larritt in 1857 (Butcher \& Flanders, 1987) and his proposed urban form has not changed significantly. Similar to Medieval European city plans, the city centre was characterised by about 20 small size rectangular grids. The street tended to be wide and the street network was designed with a series of roundabouts centred to the Bendigo Town Hall. The old plan provided a large reserve for government officers, courts, police barracks and prison in the Bendigo CBD area. Even though residential developments were proposed in the inner city CBD area, such residential developments never materialised. It appears that residential areas were also designed in the areas quite away from the CBD area. The original plan also designed a market reserve and city square in centre of the city.

Considering the original city plan, the street network and the urban form generally seem to be coherent and aesthetically pleasing however, it tends to be inflexible in terms of human movements and sometimes people dislike sharp turns, so shortcuts were created through the partially-occupied grid (Kostof, 1991). It is also apparent that since inner city residential developments were not implemented, the CBD area may have been less vibrant at night. Recent planning and design policies (1980s to present) From 1980s onwards, to a lesser extent new urbanism design principles seemed to influence the Bendigo CBD design process. The Bendigo Council adopted some important policies relevant to housing and other services from 1980 - 2000. The Council adopted multi unit residential code in 1982 (City of Bendigo, 1982). This new policy proposed flats, row houses, units in the CBD area. The minimum site area was to be 460 sq.m with 2 storeys and 3 storeys with special consent. Guidelines were also proposed to provide lighting of street, access lanes and pedestrian paths.

Bendigo city council proposed a plan called the Bendigo 2020 Strategy in 1990 (LoddonCampaspe Regional Planning Authority, 1990). The plan addressed several concerns relevant to liveability and safety such as residential, commercial development, office development, and transport and accessibility aspects. The plan encouraged a range of housing options such as smaller multi-unit houses and small lot sizes. The plan stressed the importance of CBD in relation to retail activities while emphasising the need for expansion of existing activity centres in new residential areas. This plan proposed to expand the office floor space in the $\mathrm{CBD}$ area through re-establishing new office buildings and re-using existing buildings including those with heritage value. It also proposed efficient public transport system and pedestrian friendly walkways. Although these strategies have not fully materialised, some of these ideas were incorporated into the later CBD development plans such as Bendigo 2030 Residential Development Strategy and Bendigo CBD Development Plan 2005.

In the early 1990s, Bendigo Council constructed a major retail centre on the edge of the CBD which became home to some retail giants stores in Australia. Later this land area was designated as Market Place precinct. Further expansion works for the new market place were completed in early 2000 with response to study of Bendigo commercial and land strategy in 2004. Similar to modern American shopping malls, these retail spaces are enclosed spaces with ample car parking facilities. It seems these new retail space proposals have affected functionality of the CBD area to a greater extent. It has also been observed that large car park spaces allocated for Bendigo precinct shopping centre tended to be quiet spaces at night and therefore such spaces may feel uncomfortable to walk in such areas at night.

City of Bendigo adapted a new residential development strategy in 2004 (City of Greater Bendigo, 2004b). This residential strategy provided a framework on how to accommodate 
housing needs of the Bendigo Council area until 2030. It gave high priority to accommodate 954 dwellings within the city centre. It has proposed new housing options which were never mentioned in the previous plans in the Bendigo CBD area. As a result of this, the Council adopted to promote 'shop top housing' and high density apartments. Building on the multiunit residential development strategy that was adopted in 1982, the new strategy also promoted 95 multi-unit residential units in the CBD area. These higher density residential developments within the city centre area aimed to promote a critical mass of activity in the core area. Even though the construction rate of higher density residential complexes has been slow in the CBD area in recent years, it has been observed that a few higher density residential developments have emerged in the CBD area to due to this residential development.

In addition this, in 2004, the council adopted several strategies to improve the safety concerns in the CBD such as frequent safety audits, upgrade the CCTV cameras, provision of afterhours public transport options on Saturday and Sunday nights, develop a calendar of events for youths, and to review the liquor licensing policies within the CBD area. It seems that these strategies are far more to be linked with management and policing responses to feelings of safety rather than broad planning and urban design responses to perceived safety. The Council adapted its latest CDB development structure plan in 2005 (City of Greater Bendigo, 2005). It encourages new development to incorporate retail uses on the ground level to create active street frontages and encourage pedestrian movements. It discourages developments that have blank walls, non-transparent windows, empty shop fronts and offices that do not generate pedestrian flows. The current plan has also proposed a variety of residential development recommendations in inner city area. Based on previous plans, it promotes shop-top housing, student accommodation, high-density residential developments (up to 5-6 storeys) and home office developments. This, on paper at least, seems like good schemes. There is ample provision of natural surveillance for pedestrians in that people would be living there, and enough interest to make people want to visit many parts of the Bendigo CBD area. It also proposes to use heritage buildings for residential use and activities such as cafes, small shops, community services and night time markets to make the CBD more pleasant, enjoyable, remain in the city and therefore people are likely to feel safe in the CBD area.

Based on the current CBD development plan recommendations, the Bendigo Council has undertaken some development projects. In this respect Edward Street multi-storey car park project can be considered as one of the major development projects undertaken by the Bendigo Council in the CBD area in the recent times. This building provides transparent windows; provide street frontage and active frontages with shop front style services such as cafes, small shops, community services and out-door dining services. When considering housing in inner city, it appears that new CBD plan has pushed the boundaries and implemented high-density residential complexes in the CBD area.

The current CBD plan recommends several measures to improve pedestrian safety. It appears that pedestrian safety measures are likely to encourage workability and thereby such strategies enhance lively and vibrant city atmosphere. Based on CBD plan recommendations, the council has taken steps to improve the workability aspects of the CBD area in the recent

five years. A Pall Mall area has been redesigned with pedestrianised streets and children's play area. Crossing widths and Traffic speed have been reduced in Pall Mall area. Width of the foot paths have been widened on the North side of Pall Mall. Amenities such as seatings, open spaces and public toilets have been constructed inner city area to facilitate pedestrians 


\section{Discussion and Conclusions}

The review of recent plans and projects indicates that sense of safety considerations have been addressed an indirect way through Bendigo local level planning policies particularly after 1980s. In 2004 Bendigo CBD area studies related to entertainment and youth in public spaces concerned the issue of feelings of safety in CBD. According to their recommendations, safety was to be enhanced through upgrading the safety camera system and periodic safety audits in the CBD area. In the Bendigo present local plan and CBD plan safety is mainly referred to in terms of roads. For example, in 2005 CBD plan did refer to safety and this is primarily concerning safety in relation to accessibility and walkability. Likewise, there was no emphasis on perceived safety particularly at night in general in the past or present local plans.Nevertherless some informal planning discussions and spaces have been adjusted and used in informal way to enhance safety and thus this shows chapters of informality in planning (Ratnayake \& Butt, 2018). This may be due to the cross cultural interactions and international visit of planner. These international field visits may have influenced and broaden the safety design aspects of city centres (Ratnayake, Butt \& Budge, 2009; Ratnayake, 2015; Butt, Ratnayake \& Budge (2016)

In more recent years the council has taken some steps to make the CBD area active and therefore city users particularly at night will have an optimistic future in relation to sense of safety to a certain extent, if new policies are materialised. Policies have been introduced to encourage higher density housing and as a result new housing has been brought back into the CBD, but only in certain sites and still away from the inner city area. It seems that permissible height level of the higher residential developments are mainly four stored buildings due to heritage character of the city as well as conservative ideas of the community (Budge, 2003). It appears that the present allowable building height level is low compared to regional city centres in some developed and developing countries. The new CBD plan has also encouraged shop owners to make better use of the space above their premises. This will provide better surveillance for the street and also increase the security of the shop as somebody will be in the shop at all times. Such will increase pedestrians' walkability and movements (Ranasinghe, Amarawickrama \& Rathnayake, 2016). The attention has been paid to encourage mixed land uses in the CBD area. This will lead to greater surveillance and potentially more pedestrians on the street at all times of day, thereby making them safer.

\section{References}

Bendigo Historical Society. (2011) 'Our Society's History in Brief'. from http://www.bendigohistory.com/

Budge, T. (2003) 'Country Towns: More Than Just Statistics', Sustaining Regions' 3 (1): 2537.

Butcher, M., and Flanders, G. (1987) Bendigo Historic Buildings. Maryborough: National Trust of Australia (Victoria).

Carthew, S., and Allan, M. (2005) 'Strategic Planning in Regional Cities- New Conceptions', paper presented at the State of Australian Cities Conference, Griffith University, South East Queensland, Australia, 30 November - 2 December

City of Bendigo. (1982) Multi-Unit Residential Development Code. Bendigo: City of Greater Bendigo.

City of Greater Bendigo. (2004a) Entertainment Precinct Working Group Findings. Bendigo: City of Greater Bendigo.

City of Greater Bendigo. (2004b) Residential Development Strategy. Bendigo: City of 
Greater Bendigo.

City of Greater Bendigo. (2013) City of Greater Bendigo Planning Scheme. Bendigo: City of Greater Bendigo.

Crowe, T. (2000) Crime Prevention Through Environmental Design (2 ed.). Boston -

Butterworth: Heinman.

Davis, M. (1999) Ecology of Fear. New York: Vintage Books.

Gates, R. L., and Stout, F. (2003) The City: A Reader. London: Routledge.

Isnard, A. (2001) 'Can Surveillance Cameras be Successful in Preventing Crime and

Controlling Anti-Social Behaviours?' paper presented at the Character, Impact and

Prevention of Crime in Regional AustraliaConference, Townsvill, 2-3 August.

Jacobs, J. (1961) The Death and Life of Great American Cities. New York: Vintage.

Koskela, H., and Pain, R. (2000) 'Revisiting Fear and Place:Women's Fear of Attack and the Built Environment', Geoforum 31(2): 269-80.

Kostof, S. (1991) The City Shaped: Urban Patterns and Meanings Through History. London: Thames and Hudson.

Loddon-Campaspe Regional Planning Authority. (1990) 'Bendigo 2020 Strategy'. Bendigo:

Loddon-Campaspe Regional Planning Authority.

Lorenc, T., Petticrew, M., Whitehead, M., Neary, D., Clayton, S., Wright, K., and Renton, A. (2013) 'Fear of Crime and the Environment: Systematic Review of UK Qualitative Evidence', BMC Public Health 13(496)

Ratnayake, R. (2017). Sense of safety in public spaces: university student safety experiences in an Australian regional city. Rural Society, 26(1), 69-84.

De Silva, C. S., Warusavitharana, E. J., \& Ratnayake, R. (2017). An examination of the temporal effects of environmental cues on pedestrians' feelings of safety. Computers, Environment and Urban Systems, 64, 266-274.

Ratnayake, R. (2013). Environmental features and sense of safety. WIT Transactions on Ecology and the Environment, 179, 377-388.

Ratnayake, R. (2015). Traditional Small Retail Shops vs. Emerging Supermarkets and Shopping Malls in a Sri Lankan City. Bhumi, The Planning Research Journal, 4(1).

Ratnayake, R. G., Butt, A., \& Budge, T. M. (2009). Cross-Cultural Learning from the Tsunami: Professional Planners from Australia and Sri Lanka.

Ratnayake, R., \& Butt, A. (2018). Encounters with the unfamiliar: international planning education. International Planning Studies, 23(1), 51-64.

Ratnayake, R. (2016). Fear of crime in urban settings: influence of environmental features, presence of people and social variables. Bhumi, The Planning Research Journal, 3(2).

Butt, A., Ratnayake, R., \& Budge, T. (2016). Planning education and inter-cultural collaboration: awareness, innovation, reflection and preparation for practice. Bhumi, The Planning Research Journal, 3(1).

Ranasinghe, G., Amarawickrama, S., \& Rathnayake, R. (2016). A Study to Compare the Level of Walkability in Two Urban Neighborhoods of Sri Lanka. International Journal of Engineering Research and General Science, 4(1), 6-13.

Ratnayake, R. (2014). Using walk-recordings and images-how students experience safety in a city centre.

Trench, S., and Tiesdell, S. (1991) 'Safer Cities for Women: 'Perceived Risks and Planning Measures', Town Planning Review, 63(3): 279 - 96.

Victoria Police. (2012) Crime Statistics. Melbourne: Victoria Police.

Winkel, F. W., and Vrij, A. (1991) 'Characteristics of the Built Environment and Fear of Crime: A Research Note on Interventions in Unsafe Locations', Deviant Behavior 12(2): 230-15. 